\title{
Oleksandr Lototskyi and Ukrainian Autocephaly
}

Author(s): Petro Zakharchenko, Ivanna Matseliukh

Source: Kyiv-Mohyla Humanities Journal 6 (2019): 149-16o

Published by: National University of Kyiv-Mohyla Academy

http://kmhj.ukma.edu.ua/ 


\title{
Oleksandr Lototskyi and Ukrainian Autocephaly ${ }^{1}$
}

\author{
Petro Zakharchenko
}

Taras Shevchenko National University of Kyiv, History of Law and State Department

\section{Ivanna Matseliukh}

Taras Shevchenko National University of Kyiv, History of Law and State Department

\begin{abstract}
This article analyses the ideas and works of Oleksandr Lototskyi in connection with the autocephaly of the Ukrainian Orthodox Church. Lototskyi was a prominent scholar and politician during the Ukrainian revolution of 1917-1919. The chronology of Lototskyi's beliefs as they developed, ranging from the support of the autonomy of the Church to the idea of autocephaly is reviewed in detail against the background of historical events. Lototskyi's representations on behalf of the state at the All-Ukrainian Orthodox Church Sobor in November 1918 in support of Church independence showcased his convictions. The idea was incorporated by the Directory of the UNR into the Law "On the Highest Church Government of the Ukrainian Autocephalous Orthodox Church.” The article shows that the paradigm of autocephaly, as envisioned by Lototskyi and exemplified through his actions whilst Minister of Confessions, became the cornerstone of modern Ukrainian philosophy in favor of religious independence.
\end{abstract}

Key Words: autocephaly, Oleksandr Lototskyi, Orthodoxy, Ukraine, Ukrainian revolution, law, history.

\section{讨}

The problem of the national identity of a recently independent state is often exacerbated by religious connections to former usurpers, despite secular government. Although Ukraine became geopolitically independent from the Soviet Union and was internationally recognised as such in 1991, the religious institutions in the country remained under the control of the Eastern Orthodox Church, headquartered in Russia (knows as the Moscow Patriarchate). Petitions to separate the Kyiv Patriarchate from the control and influence of its Eastern neighbour were submitted twice to the highest Orthodox authority of the time - the Ecumenical Patriarchate of Constantinople, but were not successful. A more recent attempt, earlier this year, brought long-awaited independence and much jubilation to Ukraine's church-goers: the Ukrainian Orthodox Church gained recognition as being autocephalous, that is self-governing.

Attempts to achieve this during the Ukrainian revolution of 1917-1921 followed the same patterns. At that time the leader of the movement for Ukrainian religious

1 Adapted into English with the linguistic and stylistic support of Anastasia Tropsha, BA (Oxon), LLM (LSE). 
independence and a key contributor to the wider political debate was well-known writer and politician Oleksandr Lototskyi (1870-1939). ${ }^{2}$

Lototskyi's background is helpful in understanding his radical thoughts and undying support for Ukrainian independence, both through politics and religion. He was born into a clergyman's family in Podilia (West Ukraine), where he spent his younger years and became acquainted with culture, religion, and literature. Ivan Nechui-Levytskyi's Khmary and Taras Shevchenko's Kobzar, both famously patriotic works, left a lasting impression on the future philosopher, as confirmed in his memoirs. ${ }^{3}$

Having chosen to pursue religion academically, Lototskyi studied at and graduated from the Podolian Theological Seminary and the Kyiv Theological Academy, engaging actively in the young spiritual community through setting up student societies to further Ukrainian liberal thought, as well as preparing publications on the history of the Ukrainian and Belarusian Orthodox Churches. ${ }^{4}$ These works were published in Zapysky naukovoho tovarystva imeni Shevchenka, Kyivska starovyna and Lvivska Pravda, albeit without Academy approval. ${ }^{5}$

Occupying a government post in St. Petersburg after his graduation, Lototskyi continued his pro-Ukrainian grassroots movement, establishing close ties with local Ukrainians, activists, and like-minded public figures including Mykhailo Hrushevskyi, a prominent historian and statesman.

Lototskyi's contemporaries described him as energetic, hardworking, and dedicated to Ukrainian affairs, which always played a primary role in his life. We see this in the various projects which he undertook and that became possible due to the democratic transformations that followed the First Russian Revolution of 1905 . Lototskyi obtained permission from the Orthodox Synod to publish a Ukrainian translation of the New Testament to support the national movement and foster the use of the language, which had been subject to censorship for many decades in the Russian Empire. ${ }^{6}$ The publication, however, did not have significant effect on the everyday usage of Ukrainian. The language continued to suffer a peripheral role as a secondary language, often viewed as a local dialect, ${ }^{7}$ in many regions russianized during imperial rule. In fact, readings from the New Testament in Ukrainian were allowed only once yearly. ${ }^{8}$

2 A graduated of the Kyiv Theological Academy, specialty in Ukrainian canon law history.

3 Oleksandr Lototskyi, Storinky mynuloho [Pages of the Past], vol. 1 (Warsaw, 1933), 19.

4 Ihor Hyrych, "Oleksandr Lototskyi i Mykhailo Hrushevskyi. Do istorii spivpratsi na hromadskii nyvi [Oleksandr Lototskyi and Mykhailo Hrushevsky: On the History of Cooperation in the Public Field]," Arkhiry Ukrainy 5-6 (2016): 20-34.

$5 \quad$ Ivan Vlasovskyi, "Oleksandr Lototskyi yak tserkovnyi diiach [Oleksandr Lototskyi as a Church Figure]," in Lytsar pratsi i oboviazku: Zbirnyk, prysviachenyi pamiati profesora Oleksandra Lototskoho-Bilousenka (Toronto; New York: Yevshan-zillia, 1983), 39-48. Ivan Vlasovskyi, Narys istorii Ukrainskoi Pravoslavnoi Tserkvy [An Essay on the History of the Ukrainian Orthodox Church] (New York: Ukrainska Pravoslavna Tserkva, 1957), 293-99.

7 Vlasovskyi, Narys istorii Ukrainskoi Pravoslavnoi Tserkvy, 293-99.

8 Vlasovskyi, “Oleksandr Lototskyi yak tserkovnyi diiach,” 39-48. 
Following the February Revolution of 1917 a very vibrant Ukrainian national movement emerged. The establishment of the Ukrainian Tsentralna Rada (UTsR) as Ukraine's representative organ in early March 1917 turned the attention of the entire nation toward Kyiv, as the epicentre of this emerging movement. Lototskyi welcomed these events with great enthusiasm.

After a short time in office as the gubernial commissar ${ }^{9}$ of Bukovyna and Pokuttia, having been appointed by the Provisional Government, Lototskyi moved to Kyiv. This was the most prolific period of his activity as a progressive ideologist and supporter of Ukrainian autocephaly. Initially Lototskyi became a General Records Keeper ${ }^{10}$ in Vynnychenko's government. ${ }^{11}$ On August 21, 1917 he was elected to the new parliament after an election in the UTsR. ${ }^{12}$

Religious affairs had always played an integral part of the personal and political life of Lototskyi. As he came to occupy higher positions in the government of Ukraine, he maintained connections with grassroots initiatives directed at modernizing spiritual institutions in line with political changes. As the only government official with formal theological education, Lototskyi considered it his moral obligation to bring the spirit of national rebirth to the Church, which at the time still found itself in the hands of conservative Russian forces.

The first project which Lototskyi embarked on in his capacity as a state official was the creation of a separate body within the General Secretariat to serve as a liaison between the government and religious organizations across Ukraine. It is worth mentioning that in the Russian Empire the Church was not only not separated from the state, but in such areas as the registration of births, marriages, and other civil matters, it was an indispensable administrative tool. The existing mechanism, based on the incorporation of the Church into the body of the state, had lasted for almost a millennium. The understanding of the influence and scope of the penetration of this organisation under the control of the recent usurper was another reason for Lototskyi to raise the issue of the creation of an appropriate body that would reassign "administrative affairs as being within the scope of government activity." 13

However, change did not come easily. At any rate, until the voluntary resignation of Lototskyi from the post of General Records Keeper on November 20, 1917, we have not discovered any written evidence of Lototskyi proposing these plans for the government agenda. This may have been hindered by an overwhelming quantity of much more fundamental issues faced by the brand new government following the revolution, as well as the strong secular policies of the ruling parties, the Socialist-Revolutionaries and

9 Similar to a governor at the time.

10 Similar to State Secretary.

11 Dmytro Doroshenko, "Lytsar pratsi i oboviazku [A Knight of Labor and Duty]," in Lytsar pratsi i oboviazku: Zbirnyk, prysviachenyi pamiati profesora Oleksandra Lototskoho-Bilousenka

(Toronto; New York: Yevshan-zillia, 1983), 17-23.

Ukrainska Tsentralna Rada: dokumenty i materialy [The Ukrainian Central Rada: Documents and

Materials], vol. 1 (Kyiv: Naukova dumka, 1996), 264-65.

Oleksandr Lototskyi, “Znevazhena sprava [A Disgraced Matter]," Tryzub 12 (1927): 7. 
Socialist-Democrats in the UTsR. Non-interference in the internal affairs of the Church was considered to be a prima facie principle by both groups of socialists.

During his time abroad, Lototskyi remembered the lack of action on the part of the government with anguish, disagreeing with its lack of engagement in connection to the "revolutionary church issue." He is quoted to have said:

Our politicians entirely disregarded the significance of the church issue unnecessarily, and it is to the detriment of matters of national importance. Religion has always been and remains a constant reality of life at all its stages, no one has succeeded in eradicating religious ideas from the consciousness of human beings so far, regardless of the number and diversity of attempts. ${ }^{14}$

Lototskyi considered the Church to be a suitable guide for the ideas of Ukrainian national unity, as the church was the closest to people at ground level, an integral part of many local communities, assisting with both spiritual issues and everyday concerns, earning a steadfast reputation as a cornerstone of Ukrainian society. Lototskyi stated: "Through its institutions the Church influences the very conscience of the people, the sphere which is hard to penetrate even for those who consider themselves to be the true friends of the people." ${ }^{15}$

As this article has been detailed in its biographical analysis and relies upon it in later sections, this would be a convenient place to identify certain inaccuracies in popular knowledge about Lototskyi. In one of his numerous works devoted to Lototskyi, Shvydkyi alleges that at the meeting of the General Secretariat on November 25, 1917 Lototskyi was asked to draft a resolution regarding the establishment of a government body for the administration of theological issues. ${ }^{16}$ The statement is not true because no church issues were considered at the government meeting on that particular day. Besides, as mentioned above, five days before the events described by the author in his monograph, the government accepted the voluntary resignation of the General Records Keeper. The importance of this clarification lies in that during the initial period of its activity, the UTsR, its General Secretariat, and other administrative institutions did not express any interest in the operation of the Orthodox Church in Ukraine, they did not feel threatened by its activity and did not try to break its connection to the Russian Orthodox Church (ROC).

After the Bolshevik Revolution of 1917 the church issue drew attention once again, this time nationwide. For over two centuries the Church had been in the tight grip of

\footnotetext{
14 Lototskyi, "Znevazhena sprava," 7.

15 Oleksandr Lototskyi, "Tserkovna sprava na Ukraini [Church Affairs in Ukraine]," Literaturnonaukovyi visnyk 22.5 (1923): 61-70.

16 Vasyl Shvydkyi, Oleksandr Lototskyi: uchenyi, hromadskyi diiach, polityk (189o-1930-ti rr.) [Oleksandr Lototskyi: Scholar, Public Figure, Politician (189os-193os)] (Kyiv: Instytut istorii NAN Ukrainy, 2002), 139.
} 
the government, without "a canonic patriarch or council (Sobor), and the relationship between local church institutions (eparchies) was maintained via non-church channels due to parallel networks in administrative institutions." 17 Recent developments necessitated large-scale reforms in the ROC. The Local (Pomestnyi) Council was convened in Moscow with sessions taking place from August 1917 to September 1918. As a result of its year-long deliberations, the Russian Patriarchy was restored (November 10 (October 28), 1917) with the retention of the Synod and Supreme Church Council. The process of Church reformation had begun.

The situation was complicated in Ukraine because the problems of the Church overlapped with state formation. Under these conditions, pro-Ukrainian church officials and the Orthodox community became increasingly concerned with the issue of autocephaly or, at least, the autonomy of the Church. The first to support autocephaly were the Poltava clergy, who expressed support for the separation of the Ukrainian Church from Moscow at the eparchial congress in May 1917..$^{18}$ A year later, on April 28, 1918 a group of laity "from different parts of Ukraine" appealed to the Department of Confessions of the Ukrainian National Republic, petitioning the authorities to "appeal to the Patriarch of Constantinople, since the Ukrainian Church should have a hierarchical succession to the Apostolic Christian Church by the blessing of the Patriarch of the formation of the Ukrainian Orthodox autocephaly." 19

Ukrainian authorities could not ignore the new realities in the day-to-day operations of the Ukrainian Church. Therefore, with the dissolution of the UTsR, a coup d'état in Ukraine, and Skoropadskyi's rise to power, the need for specialists like Lototskyi increased significantly. Returning to government work under a new political regime proved more fruitful for Lototskyi, since Skoropadskyi's theological education informed his governance and subsequent diplomacy, scholarly achievements, teaching, and academic work. Hence, Lototskyi was the first person to be offered the position of Minister of Confessions of the Ukrainian State, which came into existence on April 29, 1918. After a brief hesitation, the offer was rejected.

In January 1919, recalling this episode, indicative of the political whirlwind of May 1918, while testifying before the Supreme Investigative Commission of Skoropadskyi's government, Lototskyi said: "Two days later I received a new telegram with an offer to

17 Tetiana Yevsieieva, "Vyshche tserkovne upravlinnia i ukrainska derzhava 1917-1918 rr: konflikt 'natsionalizmiv' u pravoslavnomu poli [The Higher Church Administration and the Ukrainian State of 1917-1918: The Conflict of 'Nationalisms' in the Orthodox Field]," accessed March 20, 2019, dspace. nbuv. gov. ua/bitstream/handle/123456789/50684/o2-Evseeva. pdf?sequence.

18 Nadiia Shyp, Tserkovno-pravoslavnyi rukh v Ukraini (poch. XX st.) [The Church Orthodox Movement in Ukraine (Beginning of the 2oth Century)] (Kyiv: Instytut istorii NAN Ukrainy, 1995), $40-41$.

19 Tsentralnyi derzhavnyi arkhiv vyshchykh organiv derzhavnoi vlady i upravlinnia Ukrainy. Ministerstvo ispovidan Ukrainskoi Derzhavy [Central State aArchive of Higher Government Authorities of Ukraine. Ministry of Confessions of the Ukrainian State], f. 1071, desc. 1, no. 103, pp. 1-1 back. 
take up the post of Minister of Confessions from the Head of the Council of Ministers, which I rejected by telegram, considering this offer to be a personal invitation made without prior agreement with political parties." ${ }^{20}$ It took several months for Lototskyi to accept a repeated offer to take up the post despite the lack of prior party-political consent. He accepted it eventually because, since the beginning of the Ukrainian revolution, the Ukrainian state had addressed religious issues on a constitutional level, recognizing "the Christian Orthodox faith to be fundamental." ${ }^{21}$ Such a decision was consonant with Lototskyi's perception of the Church's role within state governance.

Summing up his activity as Hetman in his memoirs, Skoropadskyi noted that in 1918 the movement in support of autocephaly and self-governance of the Ecumenical Orthodox Church (independent of the Russian Orthodox Church) became very popular in Ukraine. The leader of the state himself had never been a supporter of autocephaly for the Ukrainian Orthodox Church and clearly stated this in his memoirs. ${ }^{22}$ Speaking as Head of the Ukrainian State at the eighth session of the All-Ukrainian Orthodox Church Sobor, held on July 6, 1918, Skoropadskyi stressed the necessity of "all the issues of the Ukrainian Church being resolved here in Ukraine, and only then the fruits of the work and will of the people will bring about results." ${ }^{23}$ As we can see, the Head of State pointed out only certain key aims, not indicating his plans for the future of the Church, while more specificity and certainty from secular authority at this critical time was expected.

In general, Skoropadskyi never spoke in support of Ukrainian autocephaly, but some members of his government did. Namely the Ministers of Confessions Zinkivskyi and Lototskyi, who formed the principles of its internal policy to support a national Orthodox Church. ${ }^{24}$ At the beginning of his political activity, Zinkivskyi preferred the organization of church administration on the principles of autocephaly and, under the conditions of Church Sobor operation and the dominant moods within it, he agreed to the autonomy of the Ukrainian Church, ${ }^{25}$ considering that "the issue of autocephaly, the

$20 \quad$ Oksana Ivantsova, ed., Hetman P. Skoropadskyi. Ukraina na perelome. 1918 god: sbornik dokumentov [Hetman P. Skoropadskyi. Ukraine on the Brink. 1918: A Collection of Documents]

(Moskow: Politicheskaia entsyklopediia, 2014), 839.

"Zakon pro tymchasovyi derzhavnyi ustrii Ukrainy (kviten 1918) [Law on the Interim Governmental System of Ukraine (April 1918)]," in Khrestomatiia z istorii derzhavy i prava Ukrainy (z naidavnishykh chasiv do kintsa XX stolittia), vol. 2 (Kyiv: In Yure, 200o), 47. Pavlo Skoropadsky, Spohady (kinets 1917-hruden 1918) [Memoirs (End of 1917-December 1918)] (Kyiv: Instytut ukrainskoi arkheohrafii ta dzhereloznavstva im. M. S. Hrushevskoho, 1995), 199.

23 Tsentralnyi derzhavnyi arkhiv vyshchykh organiv derzhavnoi vlady i upravlinnia Ukrainy, f. 1071, desc. 1, no. 220, p. 38 .

Vasyl Ulianovskyi, Tserkva v Ukrainskii Derzhavi 1917-1920 rr. (Doba Hetmanatu Pavla Skoropadskoho) [The Church in the Ukrainian State 1917-1920: Era of the Hetmanate of Pavlo Skoropadskyi] (Kyiv: Lybid, 1997), 230.

25 Bohdan Knavarivskyi, Orhanizatsiia upravlinnia tserkovnymy spravamy v uriadi P. Skoropadskoho [The Organization of Church Affairs Administration in the Government of 
Ukrainianization of the worship of life can wait." ${ }^{26}$ Lototskyi, on the other hand, was a consistent supporter of revolutionary transformations within the Church, including the achievement of its independence.

It was Lototskyi who chaired Cabinet meetings in the last few weeks of the Ukrainian State's existence. At that time the scholar showed himself to be a constant supporter of the creation of an independent national Church. "It was thought, of course, that the future creation of the Ukrainian Church was one of the central interests of Lototskyi" - indicated a contemporary. ${ }^{27}$

Lototskyi always demonstrated civility and tolerance in his assessment of opponents and the activities of his predecessors. While Zinkivskyi, the first Minister of Confessions in the Hetman government, called Lototskyi one of the most cruel personalities in Ukrainian history, who "without batting an eye, could voice a death sentence," 28 Lototskyi, in his turn, highly appreciated the moral qualities of his predecessor as "a person of his own personal dignity, but without a clear national opinion and solid fortune." 29

Holding a government post, Lototskyi primarily focused on promoting the idea of autocephaly and on convincing the members of the government of the Ukrainian State of its extreme importance. For the purpose of the quick implementation of the idea, he took several unpopular steps, involving in the work of the Ministry of Confessions activists of pro-Ukrainian movements, supporters of the independent Orthodox Church. The pressure exerted by the Ministry on the representatives of the church hierarchy increased. Lototskyi constantly claimed that it would be possible to stop the funding of Church Sobor meetings in the event of their opposition to the implementation of the idea of autocephaly, thus forcing church leaders to adopt the decision that was necessary for the state..$^{30}$

His confidence in the correctness of his actions and expressed ideas was not based on his arrogance, but on his convictions and knowledge of the history of autocephalous church importance and its effect for national independence. He was deeply convinced of the indispensability of obtaining the status of independence by the Ukrainian Church, as far as he considered the existence of profound insurmountable differences between the culture and spirituality of Ukraine and Russia. "Two worlds encountered themselves in the Moscow-Ukrainian cultural conflict, which used to be termed as Greek and Latin ones, in fact, it was a struggle between two cultures, East-Asian and

P. Skoropadskyi] (Lviv: Ukraina, 2004), 8o.

26 Tsentralnyi derzhavnyi arkhiv vyshchykh organiv derzhavnoi vlady i upravlinnia Ukrainy, f. 1071, desc. 1, no. 68, p. 4.

27 Ivan Korovytskyi, “Oleksandr Lototskyi u Varshavi [Oleksandr Lototskyi in Warsaw]," in Lytsar pratsi i oboviazku: Zbirnyk, prysviachenyi pamiati profesora Oleksandra Lototskoho-Bilousenka (Toronto; New York: Yevshan-zillia, 1983), 74-84.

28 Shvydkyi, Oleksandr Lototskyi, 145.

29 Lototskyi, “Tserkovna sprava na Ukraini," 66.

30 Knavarivskyi, Orhanizatsiia upravlinnia tserkovnymy spravamy, 104 
Western-European, in the spirit of the modern development of geopolitical processes," asserted the scholar in his later publications. ${ }^{31}$

The real apotheosis of the true intentions in the activity of Lototskyi as Minister of Confessions of the Ukrainian State was his speech at the autumn session of the All-Ukrainian Orthodox Church Sobor, which took place in Kyiv on November 12, 1918, when he declared the autocephaly of the Ukrainian Church on behalf of the Cabinet of Ministers. ${ }^{32}$ The decision of the Government of the Ukrainian State was not legally valid, since without the signature of the Head of the State it did not have the effect of a legislative act. Skoropadskyi did not give his consent. That is why researchers of the Ukrainian diaspora call it nothing more than a "declarative speech." 33

Nevertheless, the brief but meaningful speech by Lototskyi has been of a great importance for both those times and today, due to the embodiment and popularisation of the idea of the autocephaly of the Ukrainian Church. We will consider its key elements in more detail.

The main message of the Minister of the Cabinet of Ministers of the Ukrainian State to the clergy, laity, and other Churches of the Orthodox world lay in the need to create within the independent state a Church with the same status. Paraphrasing Lototskyi's words, no government would agree to the fact that the Church's authority was located in another country, and it was precisely from there that constant threats came, which resulted in the abandonment of the foundations of Church unity. As far as Ukraine was in the process of its transformation into an independent state, "the Ukrainian Church should be autocephalous, under the chairmanship of the Kyiv Metropolitan, in its relations with other Churches and in canonical connections with other independent states." The last accord of the speech of the Minister was that the autocephaly of the Ukrainian Church "is a final need of our Church, our State, and our nation." 34

Lototskyi's speech on 12 November 1918 was so powerful that it has remained relevant in modern times. Seventy-three years later (November 1-3, 1991), the text of his speech formed the basis of Metropolitan Filaret's (Denysenko) of Kyiv and All Ukraine "Independent Church in an Independent State" program statement that substantiated the need for Ukrainian Church autonomy renewal. ${ }^{35}$

31 Oleksandr Lototskyi, Skhid i Zakhid u kreslenni ukrainskoi kultury [East and West in the Drafting of Ukrainian Culture] (Lviv, 1939), 13 .

32 Natalia Polonska-Vasylenko, Istorychni pidvalyny UAPTs [Historical Foundations of the UAOC] (Munich, 1964), 97. Dmytro Doroshenko, Istoriia Ukrainy, 1917-1923 [A History of Ukraine, 1917-1923], vol. 2 (Uzhorod, 1930), 333 .

Oleksandr Lototskyi, Ukrainski dzherela tserkovnoho prava [Ukrainian Sources of Ecclesiastical Law] (Warsaw: Pratsi ukrainskoho naukovoho instytutu, 1935), 133-34. 
It should be noted that the official statement of the Government of the Ukrainian State has remained a declaration. The Church Sobor, elected in its vast majority of representatives of pro-Russian episcopate and faithful, sabotaged the decision of the Government of Skoropadskyi on autocephaly and did not support it. Within a few weeks the Hetman's power was taken away by a civil riot led by the Directory of the UNR. Its leaders became entangled in the idea of the independence of the Ukrainian Church, and on January 1, 1919 the Directory of the UNR approved the Law "On the Highest Church Government of the Ukrainian Autocephalous Orthodox Church," the draft of which was made by Shelukhin, the Senator of the Ukrainian State Senate, with the participation of Lototskyi, as he himself reported. ${ }^{36}$ Undoubtedly, the most important in terms of the new legal status of the Ukrainian Church was Article 6 of the Law, which stated that "the Ukrainian Autocephalous Church with its Synod and clerical hierarchy is not dependent on the All-Russian Patriarch," and its legislative, judicial and administrative authority belongs to the All-Ukrainian Church Sobor. The law provided the basic principles of cooperation between the state and the Church, where the former maintains the latter with its own funds. ${ }^{37}$

All of Lototskyi's subsequent activity was connected with the diplomatic mission to Constantinople, which was entrusted with the task of obtaining the consent of the Ecumenical Orthodox Church in recognizing the autocephaly of the Ukrainian Church. Negotiations with the Primate of the Patriarchal See were quite successful, but the vacancy of the patriarchal chair resulted in failure to legitimize the independence of the Ukrainian Church. The final resolution of the issue of autocephaly was postponed for an indefinite period, ${ }^{38}$ but because of the defeat of the Directory of the UNR and the occupation of Ukraine by Bolshevik forces, obtaining a corresponding decision from the Patriarchate became an impossible task for Lototskyi's diplomatic mission. ${ }^{39}$

In conclusion, the significance of Lototskyi as a Ukrainian politician, scholar, and canonist, lays in his activity as one of the masterminds behind the idea of the autocephaly of the Ukrainian Orthodox Church, that in the conditions of the Ukrainian revolution 1917-1921 found a large number of supporters among the faithful and clergy as well as the leaders of the Ukrainian state. The insistence of the Minister of Confessions of the Ukrainian State led to the adoption of the Law on Autocephaly by the Directory of the UNR immediately after the fall of Skoropadskyi's regime. His participation in the

36 Lototskyi, “Tserkovna sprava na Ukraini," 68.

37 “Zakon Dyrektorii UNR 'Pro vyshchyi uriad Ukrainskoi Avtokefalnoi Pravoslavnoi Sobornoi Tserkvy' (1 sichnia 1919 r.) [Law of the the Directorate of the UNR 'On the Highest Church Government of the Ukrainian Autocephalous Orthodox Church']," Vistnyk derzhavnykh zakoniv dlia vsikh zemel Ukrainskoi Narodnoi Respubliky 1 (1919). [The Martyrology of Ukrainian Churches: Documents, Materials, Christian Self-Publishing in Ukraine], vol. 1 (Toronto; Baltimore: Smoloskyp, 1987), 16. 
negotiation process on autocephaly with the representative of the Ecumenical Patriarch points to the exclusiveness and indispensability in advancing national interests at the level of world church leaders. The path to the independence of the national Church, initiated by Lototskyi, was interrupted in Ukraine for a century. At present, a hundred years after the beginning of the process of Ukrainian Orthodox Church independence, the ideas of the prominent Ukrainian statesman have become reality.

\section{Bibliography}

Doroshenko, Dmytro. “Lytsar pratsi i oboviazku [A Knight of Labor and Duty].” In Lytsar pratsi i oboviazku:Zbirnyk, prysviachenyi pamiati profesora Oleksandra LototskohoBilousenka, 17-23. Toronto; New York: Yevshan-zillia, 1983.

Doroshenko, Dmytro. Istoriia Ukrainy, 1917-1923 rr. [A History of Ukraine, 1917-1923]. Vol. 2. Uzhorod, 193 o.

Hyrych, Ihor. "Oleksandr Lototskyi i Mykhailo Hrushevskyi. Do istorii spivpratsi na hromadskii nyvi [Oleksandr Lototskyi and Mykhailo Hrushevskyi: On the History of Cooperation in the Public Field]." Arkhivy Ukrainy 5-6 (2016): 20-34.

Ivantsova, Oksana, ed. Hetman P. Skoropadskyi. Ukraina na perelomie. 1918 god: sbornik dokumentov [Hetman P. Skoropadsky. Ukraine on the Brink. 1918: A Collection of Documents]. Moscow: Politicheskaia entsyklopediia, 2014.

Knavarivskyi, Bohdan. Orhanizatsiia upravlinnia tserkovnymy spravamy $v$ uriadi P. Skoropadskoho [The Organization of Church Affairs Administration in the Government of P. Skoropadskyi]. Lviv: Ukraina, 2004.

Korovytskyi, Ivan. "Oleksandr Lototskyi u Varshavi [Oleksandr Lototskyi in Warsaw]." In Lytsar pratsi i oboviazku: Zbirnyk, prysviachenyi pamiati profesora Oleksandra Lototskoho-Bilousenka, 74-84. Toronto; New York: Yevshan-zillia, 1983.

Lototskyi, Oleksandr. "Tserkovna sprava na Ukraini [Church Affairs in Ukraine]." Literaturno-naukovyi visnyk 22.5 (1923): 61-70.

Lototskyi, Oleksandr. "Znevazhena sprava [A Disgraced Matter]." Tryzub 12 (1927): 6-11.

Lototskyi, Oleksandr. Skhid i Zakhid u kreslenni ukrainskoi kultury [East and West in the Drafting of Ukrainian Culture]. Lviv, 1939.

Lototskyi, Oleksandr. Storinky mynuloho [Pages of the Past]. Vol. 1. Warsaw: Drukarnia OO Vasylian u Zhovkvi, 1933.

Lototskyi, Oleksandr. Ukrainski dzherela tserkovnoho prava [Ukrainian Sources of Ecclesiastical Law]. Warsaw: Pratsi ukrainskoho naukovoho instytutu, 1935.

Lototskyi, Oleksandr. V Tsarhorodi [In Constantinople]. Warsaw: Naukove vydavnytstvo im. Shevchenka, 1939 .

Martyrolohiia Ukrainskykh tserkov: dokumenty, materialy, khrystyianskyi samvydav Ukrainy [The Martyrology of Ukrainian Churches: Documents, Materials, Christian Self-Publishing in Ukraine]. Vol. 1. Toronto; Baltimore: Smoloskyp, 1987.

Polonska-Vasylenko, Natalia. Istorychni pidvalyny UAPTs [Historical Foundations of the UAOC]. Munich: B. v., 1964. 
Prelovska, Iryna. Dzherela z istorii UAPTs (1921-1930) - UPTs (1930-1939) [Sources on the History of the UAOC (1921-1930) - UOC (1930-1939)]. Kyiv: Instytut ukrainskoi arkheohrafii ta dzhereloznavstva im. M. S. Hrushevskoho, 2013.

Shvydkyi, Vasyl. Oleksandr Lototskyi: uchenyi, hromadskyi diiach, polityk (1890-1930-tirr.) [Oleksandr Lototskyi: Scholar, Public Figure, Politician (189os-193os)]. Kyiv: Instytut istorii NAN Ukrainy, 2002.

Shyp, Nadiia. Tserkovno-pravoslavnyi rukhv Ukraini (poch. XX st.) [The Church Orthodox Movement in Ukraine (Beginning of the 2oth Century)]. Kyiv: Instytut istorii NAN Ukrainy, 1995.

Skoropadskyi, Pavlo. Spohady (kinets 1917-hruden 1918) [Memoirs (End of 1917December 1918)]. Kyiv: Instytut ukrainskoi arkheohrafii ta dzhereloznavstva im. M. S. Hrushevskoho, 1995.

Tsentralnyi derzhavnyi arkhiv vyshchykh organiv derzhavnoi vlady i upravlinnia Ukrainy. Ministerstvo ispovidan Ukrainskoi Derzhavy [Central State Archive of Higher Government Authorities of Ukraine. Ministry of Confessions of the Ukrainian State]. F. 1071, desc. 1, no. 103, pp. 1-1 back.

Tsentralnyi derzhavnyi arkhiv vyshchykh organiv derzhavnoi vlady i upravlinnia Ukrainy. Ministerstvo ispovidan Ukrainskoi Derzhavy [Central State Archive of Higher Government Authorities of Ukraine. Ministry of Confessions of the Ukrainian State]. F. 1071, desc. 1, no. 220, p. 38.

Tsentralnyi derzhavnyi arkhiv vyshchykh organiv derzhavnoi vlady i upravlinnia Ukrainy. Ministerstvo ispovidan Ukrainskoi Derzhavy [Central State Archive of Higher Government Authorities of Ukraine. Ministry of Confessions of the Ukrainian State]. F. 1071, desc. 1, no. 68, p. 4.

Ukrainska Tsentralna Rada: dokumenty i materialy [The Ukrainian Central Rada: Documents and Materials]. Vol. 1. Kyiv: Naukova dumka, 1996.

Ulianovsky, Vasyl. Tserkva v Ukrainskii Derzhavi 1917-1920 rr. (Doba Hetmanatu Pavla Skoropadskoho) [The Church in the Ukrainian State 1917-1920: Era of the Hetmanate of Pavlo Skoropadskyi]. Kyiv: Lybid, 1997.

Vlasovsky, Ivan. "Oleksandr Lototskyi yak tserkovnyi diiach [Oleksandr Lototskyi as a Church Figure]." In Lytsar pratsi i oboviazku: Zbirnyk, prysviachenyi pamiati profesora Oleksandra Lototskoho-Bilousenka, 39-48. Toronto; New York: Yevshanzillia, 1983 .

Vlasovskyi, Ivan. Narys istorii Ukrainskoi Pravoslavnoi Tserkvy [An Essay on the History of the Ukrainian Orthodox Church]. New York: Ukrainska Pravoslavna Tserkva, 1957.

Yevsieieva, Tetiana. "Vyshche tserkovne upravlinnia i ukrainska derzhava 1917-1918 rr: konflikt 'natsionalizmiv' u pravoslavnomu poli [The Higher Church Administration and the Ukrainian State of 1917-1918: The Conflict of 'Nationalisms' in the Orthodox Field]," 37-82. Accessed March 20, 2019. www. dspace. nbuv. gov. ua/bitstream/ handle/123456789/50684/o2-Evseeva. pdf?sequence.

"Zakon Dyrektorii UNR 'Pro vyshchyi uriad Ukrainskoi Avtokefalnoi Pravoslavnoi Sobornoi Tserkvy' (1 sichnia 1919 r.) [Law of the the Directorate of the UNR 'On the 
Highest Church Government of the Ukrainian Autocephalous Orthodox Church']." Vistnyk derzhavnykh zakoniv dlia vsikh zemel Ukrainskoi Narodnoi Respubliky 1 (1919).

"Zakon pro tymchasovyi derzhavnyi ustrii Ukrainy (kviten 1918) [Law on the Interim Governmental System of Ukraine (April 1918)]." In Khrestomatiia z istorii derzhavy i prava Ukrainy (z naidavnishykh chasiv do kintsa XX stolittia). Vol. 2. Kyiv: In Yure, 2000.

Petro Zakharchenko is doctor of law and professor at the History of Law and State Department of the Law Faculty at Kyiv Taras Shevchenko National University. His sphere of scholarly interests include the evolution of land ownership in Ukraine, the development of legal institutes during the period of the Ukrainian Revolution in 1917-1921. He is the author of more than 13 o scholarly works devoted to the history of Ukrainian law, including seven textbooks and training course manuals on "The History of the State and the Law of Ukraine," "The History of the State and the Right of Foreign Countries," "The History of Ukrainian Law."

Ivanna Matseliukh is a candidate of jurisprudential sciences and associate professor at the History of Law and State Department of the Law Faculty at Kyiv Taras Shevchenko National University. Her research interests include the history of Ukrainian law, statehood, church legal relations and their genesis in Ukraine. She is the author of more than 100 scholarly works devoted to the history of church law, including two monographs: The Sources of Church Law in Ukrainian Medieval Times (Kyiv, 2015) and Legal Liability in the Church Law of Medieval Ukraine (Kyiv, 2015). She is currently completing her doctoral thesis. 